\title{
THE CONCEPT OF ISLAMIC EDUCATION DEVELOPMENT BASED ON THE THEORY OF FITRAH
}

\author{
Triwidyastuti \\ Master Program of Islamic Education, Faculty of Islamic \\ Studies, Islamic University of Indonesia \\ Maragustam Siregar \\ Sunan Kalijaga State Islamic University of Yogyakarta
}

Email: triwidyastuti1@yahoo.com E maragustam@uin-suka.ac.id

\section{Abstract}

Many theories are developing in understanding the educational goals. However, not all theories can examine how human develop optimally along with all their potentials. So, there is a need for discussion of the concept of development of Islamic education through the comparative analysis of the theory of Fitrah in Islam and the theories of Nativism, Empiricism and Convergence as the theoretical basis which aims to understand better Islamic education and contribute to its further conceptual development. To this end, this study offers a comparative analysis of the theory of Fitrah in Islam and theories of Nativism, Empiricism and Convergence to search for the construction of Islamic education development. The study uses a library research method which is descriptive-analysis in nature while its analysis uses contentanalysis. The primary book source of this study is Yasien Muhammad's book, Fitrah: The Islamic Concept of Human Nature and Murtadha Muthahari's Al-Fitrah, translated into Indonesian by Afif Muhammad as "Bedah Tuntas Fitrah". In term of the role of God in developing human beings' potentials (fitrah), this research found that: First, God is the driving 
force (Causa Prima). Second, God develops human nature genetically. The research also found that the construction of development of Islamic education based on the theory of Fitrah has two functions: first, Islamic education is an antidote of secularism in the world of Islamic education. Second, it seeks to shape a quality or civilized human being according to the Qur'anic values.

Keywords: Theory of Fitrah, Theory of Nativism, Theory of Empiricism and Convergence Theory

\section{A. Introduction}

Islamic education is the totality of Muslim human activity that is carried out seriously, consciously and continuously based on faith and piety to Allah the Almighty. It aims to prepare students to become human resources who have strong, holistic and quality mental, character, and personality and who are qualified intellectually and morally to be able to live independently. ${ }^{1}$

The goal of education in general and especially Islamic education is not merely as the process of transferring knowledge, but also the process of transferring Islamic values. The purpose of Islam essentially is to make devoted people who can achieve success in the world and the hereafter (muflihun). ${ }^{2}$ The principle of Islamic education is upheld by universal truth and stems from the philosophical view of Islam on the universe, human, society, science and morals, which comes from the Qur'an and Hadith. ${ }^{3}$

1 Faisal Ismail, Paradigma Pendidikan Islam: Analisis Historis, Kebijakan, dan Keilmuan (Bandung: Rosdakarya, 2017),p. 3.

2 A.Syafi' Ma'arif, Pendidikan di Indonesia: Antara Cita dan Fakta (Yogyakarta: Tiara Wacana, 1991), p. 43.

3 Achmad Arifudin, "Prinsip prinsip pendidikan islam perspektif al-quran dan hadis," (Education, 23:10:46 UTC), https://www.slideshare.net/achmadarifuddin/prinsip-prinsip-pendidikan-islam-perspektif-alquran-dan-hadis. 
Departing from the above notions, it is interesting and important to discuss the concept of development of Islamic education. This is because the process of Islamic education itself must be carried out continuously. As stated in a famous phrase: "Seek knowledge from the cradle till the grave".

Specifically, the discussion on the development of the Islamic education system begins with a comparative analysis related to human nature with the principles of Western educational philosophy. This discussion will pave the way for the construction of Islamic Education based on the fitrah theory although this may have been widely discussed. Notwithstanding, practitioners or academician in the world of education should understand how the concept of Islamic education related to human, environment or heredity.

Humans are creature who are connected to society, environment, self and God. Essentially, humans are defined as 'abdun, khalifah, annas, al-basyar, the children of Adam and al-Insan. The philosophical environment is something that exists outside of humans and has meaning or benefits. So, the environment basically affects the process of Islamic education. Heredity is called as al-warisah and Islam is very attentive to this in the formation of one's personality and directs it in a positive way. ${ }^{4}$

Human life is influenced by heredity, environment and free will over the power of God. A bad environment is an external influence affecting the positive nature of monotheism. Just as a good environment will also have an effect. This is what is meant by Islamic education.

Then the Fitrah Theory above needs to be discussed in relation to heredity and talent or innate in the context of the Nativism, Empiricism and Convergence theories as well as the environmental factors effecting human development.

4 Maragustam, Filsafat Pendidikan Islam: Menuju Pembentukan Karakter Menghadapi Arus Global (Yogyakarta: Kurnia Alam Semesta, 2016), p. 102-104. 


\section{Triwidyastuti}

\section{B. Theory of Fitrah in Islamic Education}

If we call something fitrah, we mean that it comes from within man. This means since a man was created natural things have been implanted in him. ${ }^{5}$ While the mention of theory here comes from the concept or views of certain scholars related to fitrah, which is then tested empirically and result in the theory of fitrah. The views of the philosophers of Islamic education depart from QS. Ar-Rum verse 30 or Hadith narrated by Muslim about human nature.

"A baby is not born (into this world) except in holiness (fitrah). Then it was his parents who would make him Jewish, Christian, or Majusi --as the animals were born without any flaws. So, do you feel any defects? 'Then Abu Hurayrah said; 'If you want, then read the word of God which says:' ... remains with the nature of Allah who created man according to his nature. There is no change in the nature of God. " (Surah Ar Ruum (30): 30) .

Murthada Muthahari argues that fitrah implies the state by which man is created. That is, God created man in certain circumstances, in which there are specialities that God placed on him when he was created. That is the state of his nature., implies the state by which man is created. That is, God has created man in certain circumstances, in which there are specialities that God placed on him when he was created. That's the state of his nature. ${ }^{7}$

Since Allah`s fitrah is engraved upon the human soul, mankind is born in a state in which tawhid is integral. Since tawhid is intrinsic to mans's a fitrah, the prophets came to remind man of it, and to guide him to that which is integral to his original nature. ${ }^{8}$

5 Murtadha Muthahhari, Bedah tuntas fitrah: mengenal jati diri, hakikat dan potensi (Jakarta, Indonesia: Citra, 2011), p. 27.

6 An Nawawi, "Darul Kutub Al- 'Ulumiyah," STUDI HADIST TENTANG FITRAH MANUSIA (Sebuah Kajian Ontologi) (blog), Desember 2014, p. 169-180, https://pecinta-araby.blogspot.com/2014/12/studi-hadist-tentang-fitrah-manusia_3.html.

7 Muthahhari, Bedah tuntas fitrah.

8 Yasien Muhammad, Fitrah the Islamic Concept of Human Nature (London: Ta-Ha Publishers, 1996),p. 16-17. 
Tab'un-originally verbal noun-signifies nature or an inborn dispotition. Its synonyms are sajjiyah, jibillah, khaliqah, tabi 'ah and mijaz. These are names for innate natural dispotition which cannot change, and which exist at birth in all human beings. ${ }^{9}$ Thus, fitrah having the same meaning as tab 'un, linguistically means an inborn natural dispotition. ${ }^{10}$

According to Yasien Muhammad, thinkers have different views or schools of thought on Islamic education in the perspective of Fitrah (tauhid, potency, purity). It also departs from the QS. Ar-Rum verse 30:

1. The Fatalist-Passive view that believes that every individual, through God's ordinance, is originally good or evil, whether this provision occurs in whole or in part according to God's plan. This view also departs from the QS. Al-A 'raf verse 172.

2. The Neutral-Passive view; the child is born in a holy state, whole and perfect, an empty state as it is, without awareness of faith or kufr, good or evil. This is similar to John Lock's tabular theory. This view also departs from the QS. Al-Nahl verse 78.

3. Positive View-Active; i.e the innate basic or human nature from birth is good, while the crime is accidental. This view also departs from the QS. Al-A 'raf verse 172.

4. Dualist-Active view; that humans from the beginning bring a dual nature. On the one hand it tends to the good, and the other side tends to evil. This view also departs from the QS. Al-Hijr verses 28-29. ${ }^{11}$

Sayyid Qutb discusses the letter of Ar-Rum verse 30, in the book "Tafseer Fi Zhilalil Quran; Under the Shade of the Qur'an "linking the nature of the human soul with this religious nature. Both come from

\footnotetext{
9 Muhammad,p. 15.

10 Muhammad, Fitrah the Islamic Concept of Human Nature.

11 Maragustam, Filsafat Pendidikan Islam,p. 124-131.
} 


\section{Triwidyastuti}

God. Both are in accordance with the name of being and both are in harmony with the other in character and direction. ${ }^{12}$

According to Hasan Langgulung, fitrah in Arabic means the creation of Allah, that is, man has been given good potential by God. Therefore, although a man is not taught he will in himself be in accordance with the teachings of religion. Man has been created according to his nature, unless the person is educated on the contrary, that is educated to deny religion. ${ }^{13}$

Fitrah etymologically can be interpreted, taking Dualist-Active view, as the potential or tendency, which both affect each other with the environment so that he grows for the better or worse. It can be concluded that the theory of fitrah results in understanding among others the tendency to tauhid or truth, the potential of goodness and potential for the religion of Islam.

Theories about heredity (al-warisah) has determined that the child will inherit traits from both parents, both moral (alkhalqiyah), kinesthetic (al-jismiyah) and intellectual (al-aqliyah), since the time of his birth. ${ }^{14}$ But it must be admitted also that heredity factor do not always plays automatically. Because of the human's free will, he will be able to defeat the influence of al-warisah and environmental factors for God's help. This is what happened to the son of Noah, whose name was Kan'an, who was disbelieving in his father's prophetic mission. ${ }^{15}$

Indeed, the story of Kan'an illustrates that in addition to heredity, environmental factors also affect humans which depart from free will. Also, in the dual-active view it is argued that man has two tendencies of good and bad.

12 Sayyid Qutb dan Siddiq Fadzil, Di Bawah Naungan Al-Quran (Kuala Lumpur: ABIM, 1981),p. 143.

13 Arham Junaidi Firman, "Paradigma Hasan Langgulung Tentang Konsep Fitrah Dalam Pendidikan Islam," Jurnal Pendidikan Islam 8, no. 2 (29 November 2017): p. 123-143.

14 Maragustam, Filsafat Pendidikan Islam,p. 105.

15 Maragustam, 105-6. 
Environment or nature has an important role in Islamic education because it is a significant element in the formation of personality and the achievement of individual desires in the general framework of civilization. ${ }^{17}$ Environment includes all the material and stimuli inside and outside the individual self, both biologically, psychologically, and socio-cultural and tradition. Thus, the environment can be interpreted physiologically, psychologically as well as socio-culturally. ${ }^{18}$

\section{Principles of Western Education Philosophy (Theory of Nativism, Empiricism and Convergence)}

According to Morris L. Bigge, the basic nature of morals is good, ugly or neutral, while human relationships with the environment is active, passive or interactive. This concept continues with the birth of Nativism, Empiricism and Convergence theories. ${ }^{19}$

\section{Theory of Nativism}

The theory of Nativism comes from the word nativus which means being born. The school of Nativism states that individual development is determined by heredity or innate factors. According to this theory every individual has brought certain traits since they were born that will determine the state of the individual concerned. According to this theory, a person's success is determined by himself. Another factor, namely the environment and experience of education will not affect the individual development. The leading proponents of this Nativism theory are Arthur Schopenhaur and Immanuel Kant. This view of Nativism does not appear to be based on God, nature, society, science and ethics.

\section{Theory of Empiricism}

The theoryofEmpiricismisa philosophicaldoctrinethat emphasizes the role of experience in acquiring knowledge and knowledge itself

16 An Nawawi, "Studi Hadist Tentang Fitrah Manusia (Sebuah Kajian Ontologi),,p.p. 169-180.

17 Maragustam, Filsafat Pendidikan Islam,p. 106.

18 Maragustam,p. 106.

19 Maragustam,p. 100. 


\section{Triwidyastuti}

and discourages the role of reason. The term empiricism is derived from Greek word emperian that means experiment or experience. As a doctrine, empiricism is the opposite of rationalism. ${ }^{20}$ The main figures of this theory of empiricism include John Locke, David Hume and Herbert Spencer. John Lock, for example, argues that humans are born like white paper or tabularasa that does not carry any basic/ innate talent. The dominant environment influences its development and truth is based on sensory experience.

\section{Convergence Theory}

The Convergence Theory comes from the word convergent which means it is toward a single point of meeting. This school holds that both basic nature (talent, heredity) and environment play an important role in the individual development. Talent is a possibility or disposition that has existed in every individual, which then due to the influence of the environment in accordance with the needs of its development will become a reality. But talents without equal environmental influences corresponding to these developmental needs are insufficient. For example, every normal human child has a talent of standing on both legs, but this talent as a possibility will not come true if the child is not raised in a human society environment. ${ }^{21}$ The pioneer of this theory is William Stern.

In the theory of convergence, education or the environment and innate play a natural role. Education in the theory of convergence can be interpreted as a help given to the students to develop good character and prevent bad carriage. Educational outcomes are largely determined by innate and environmental outcomes. ${ }^{22}$

20 Maragustam,p. 173-174.

21 Sarni Pujianto, “Teori Konvergensi dalam Psikologi," Sarni Pujianto (blog), Sabtu, Desember 2013, http://sarni72.blogspot.com/2013/12/teori-konvergensi-dalam-psikologi. html.

22 H. Abuddin Nata, Pemikiran Pendidikan Islam dan Barat (Jakarta: PT RajaGrafindo Persada, 2012),p. 251-52. 


\section{Comparative Analysis and Construction of Islamic Education Development}

1. Human nature

\begin{tabular}{|c|l|l|}
\hline No & \multicolumn{1}{|c|}{ Theory } & \multicolumn{1}{|c|}{ Analysis Results } \\
\hline a & Theory of Fitrah & $\begin{array}{l}\text { Man associated with his nature is } \\
\text { always connected with society, the } \\
\text { environment, himself, and God. }\end{array}$ \\
\hline b & Theory of Nativism & $\begin{array}{l}\text { Humans with their heredity develop } \\
\text { their personality. }\end{array}$ \\
\hline c & Theory of Empiricism & $\begin{array}{l}\text { Man is like a blank paper or a tabular } \\
\text { that has nothing in it. And gaining } \\
\text { experience from experience is a process } \\
\text { of educational development. }\end{array}$ \\
\hline d & Convergence Theory & $\begin{array}{l}\text { Human development is influenced by } \\
\text { talent/ability factor and natural factors, } \\
\text { including education and socio-culture. }\end{array}$ \\
\hline
\end{tabular}

Human Relationships with God or Religion

\begin{tabular}{|c|c|l|}
\hline No & \multicolumn{1}{|c|}{ Theory } & \multicolumn{1}{c|}{ Analysis results } \\
\hline a & Theory of Fitrah & $\begin{array}{l}\text { Human development, in addition to being } \\
\text { influenced by nature that was brought from } \\
\text { birth, is also influenced by the environment. } \\
\text { In that development, there is also the inter- } \\
\text { vention (involvement) of God by lowering } \\
\text { the values of nature at once in the process. } \\
\text { This ideology is called theo-centric human- } \\
\text { ism. }\end{array}$ \\
\hline b & $\begin{array}{l}\text { Theory of Nativ- } \\
\text { ism }\end{array}$ & $\begin{array}{l}\text { Man's development is not based on God, } \\
\text { nature, society, science and ethics. So, all } \\
\text { human potential is only pure from heredity } \\
\text { as it is. }\end{array}$ \\
\hline
\end{tabular}




\begin{tabular}{|c|l|l|}
\hline c & $\begin{array}{l}\text { Theory of } \\
\text { Empiricism }\end{array}$ & $\begin{array}{l}\text { Human development does not involve God } \\
\text { and the rationale has more role. So, all the } \\
\text { understanding of the truth is based on rea- } \\
\text { son and sensory experience. }\end{array}$ \\
\hline d & $\begin{array}{l}\text { Convergence } \\
\text { Theory }\end{array}$ & $\begin{array}{l}\text { Human development does not involve God. } \\
\text { So, understanding of the truth is based on } \\
\text { reason or anthropocentric. Absolute heredity } \\
\text { is only a factor and the environment is an- } \\
\text { other. So, all the learning process is only for } \\
\text { the pleasure. }\end{array}$ \\
\hline
\end{tabular}

2. Human Relationships with the Environment

\begin{tabular}{|c|l|l|}
\hline No & Theory Name & \multicolumn{1}{|c|}{ Analysis Results } \\
\hline a & Theory of Fitrah & $\begin{array}{l}\text { The environment in fitrah theory is as a fer- } \\
\text { tilizer or educator for the development of } \\
\text { nature (human potential). So, in this case } \\
\text { environment becomes one important factor } \\
\text { for human development. }\end{array}$ \\
\hline b & $\begin{array}{l}\text { Theory of } \\
\text { Nativism }\end{array}$ & $\begin{array}{l}\text { The environment and experience included } \\
\text { in it will not affect human development. It } \\
\text { can be said that the environment is a factor } \\
\text { that is not able to change anything from the } \\
\text { development process. }\end{array}$ \\
\hline c & $\begin{array}{l}\text { Theory of Empir- } \\
\text { icism }\end{array}$ & $\begin{array}{l}\text { The environments and experiences that fall } \\
\text { within them are important factors for hu- } \\
\text { man development. Because the experience } \\
\text { of the senses is a source of knowledge. }\end{array}$ \\
\hline d & $\begin{array}{l}\text { Convergence The- } \\
\text { ory }\end{array}$ & $\begin{array}{l}\text { Environment is an important factor besides } \\
\text { talent or descent because it affects the needs } \\
\text { of human development. }\end{array}$ \\
\hline
\end{tabular}


3. Similarities of the Fitrah, Nativism, Empiricism and Convergence Theories

\begin{tabular}{|c|c|c|}
\hline No & Theory & Similarities \\
\hline $\mathrm{a}$ & $\begin{array}{l}\text { Theory of Fitrah } \\
\text { \& Theory of } \\
\text { Nativism }\end{array}$ & $\begin{array}{l}\text { The two equally declare man can develop } \\
\text { himself and that the potential or talent of hu- } \\
\text { man innate is an important factor of human } \\
\text { development. } \\
\text { It should be note, however, that the Nativism } \\
\text { theory states that human person is deter- } \\
\text { mined only by heredity factor alone, and the } \\
\text { aim of education is to let a human or a child } \\
\text { develop with his/her nature. } \\
\text { The Fitrah theory on the other hand, states } \\
\text { that it is not just heredity factor, but also en- } \\
\text { vironmental factors and God's involvement } \\
\text { that are important in human development. }\end{array}$ \\
\hline $\mathrm{b}$ & $\begin{array}{l}\text { Theory of Fitrah } \\
\text { \& Theory of } \\
\text { Empiricism }\end{array}$ & $\begin{array}{l}\text { The two equally declare man can develop } \\
\text { himself and that environmental factors are } \\
\text { important factors in human development. } \\
\text { It's just Empirical Theory states that environ- } \\
\text { mental factors alone are needed to develop } \\
\text { human beings while the Fitrah theory also } \\
\text { states that the potential factor/heredity and } \\
\text { God's involvement are also needed. }\end{array}$ \\
\hline c & $\begin{array}{l}\text { Theory of Fitrah } \\
\text { \& Convergence } \\
\text { Theory }\end{array}$ & $\begin{array}{l}\text { The two equally declare man can develop } \\
\text { himself and that the potential or innate hu- } \\
\text { man and environmental factors is an import- } \\
\text { ant factor of human development. } \\
\text { It's just that the theory of fitrah other than us- } \\
\text { ing heredity and environmental factors also } \\
\text { involves the role of God. }\end{array}$ \\
\hline
\end{tabular}




\begin{tabular}{|l|l|l|}
\hline $\mathrm{d}$ & All theories & $\begin{array}{l}\text { All state that education is important because } \\
\text { it involves the growth of human beings to } \\
\text { their existence; to humanistic human beings. } \\
\text { In other words, education itself is the process } \\
\text { of humanizing human beings. }\end{array}$ \\
\hline
\end{tabular}

\section{Epistemological Differences}

\begin{tabular}{|l|l|l|}
\hline No & Theory & \multicolumn{1}{c|}{ Differences } \\
\hline a & Theory of Fitrah & $\begin{array}{l}\text { Epistemologically, this theory is based on the } \\
\text { doctrines of revelation, namely the Quran } \\
\text { and Hadith. So, there is God's involvement in } \\
\text { the process of education. } \\
\text { In addition to revelation, human beings are } \\
\text { also endowed with reason as a distinguishing } \\
\text { feature from other beings. They also have free } \\
\text { will: a sense to distinguish right from wrong } \\
\text { to complete nature. }\end{array}$ \\
\hline B & $\begin{array}{l}\text { Theory of } \\
\text { Nativism }\end{array}$ & $\begin{array}{l}\text { Epistemologically, this theory is based on or } \\
\text { measured by the standard of rationality. So, } \\
\text { the reason plays a role without God. } \\
\text { So, the truth in question comes from the ratio } \\
\text { alone. } \\
\text { This view of Nativism does not appear to be } \\
\text { based on God, nature, society, science and } \\
\text { ethics }\end{array}$ \\
\hline c & $\begin{array}{l}\text { Epistemologically, this theory is based on or } \\
\text { measured by power of senses as a means of } \\
\text { observation also become a source of truth. } \\
\text { So, this theory proceeds without involving } \\
\text { God. }\end{array}$ \\
\hline Empiricism & $\begin{array}{l}\text { Epistemologically, this theory is based on or } \\
\text { measured by the standard of rationality. So, } \\
\text { the mind plays a role without God. }\end{array}$ \\
\hline
\end{tabular}


5. Differences in Education Concepts

\begin{tabular}{|c|c|c|}
\hline $\mathrm{No}$ & \begin{tabular}{|l|} 
Theory \\
\end{tabular} & Differences \\
\hline $\mathrm{A}$ & $\begin{array}{l}\text { Theory of } \\
\text { Fitrah }\end{array}$ & $\begin{array}{l}\text { Viewed from the concept of education, } \\
\text { education is full of values (value bound). It } \\
\text { emphasizes good religious values that bring } \\
\text { goodness and relate God as the potential that } \\
\text { is in him without giving up the environmental } \\
\text { role as one of the supporting fact o rs of } \\
\text { education. The educational en v iron m ent is } \\
\text { built according to Islamic norms. }\end{array}$ \\
\hline $\mathrm{b}$ & $\begin{array}{l}\text { Theory of } \\
\text { Nativism }\end{array}$ & $\begin{array}{l}\text { Viewed from the concept of education, this } \\
\text { theory is very laden with value. It tends to } \\
\text { be worldly oriented being concerned of the } \\
\text { success measured as the happiness of the world } \\
\text { alone. So, arguably this theory is value-free. } \\
\text { Perhaps this is influenced by the characters } \\
\text { of its proponents who tend to be skeptical and } \\
\text { anthropocentric. }\end{array}$ \\
\hline c & $\begin{array}{l}\text { Theory of } \\
\text { Empiricism }\end{array}$ & $\begin{array}{l}\text { Viewed from the concept of education, this } \\
\text { theory is very value-laden. It tends to worldly } \\
\text { oriented and concerned with the success } \\
\text { measured the happiness of the world alone. } \\
\text { So arguably this theory is value free. It could be } \\
\text { because the the figures of this theory tend to } \\
\text { be anthropocentric such as David Hume who } \\
\text { introduced The Great Unknowing, which is not } \\
\text { recognizable. } \\
\text { The experience taken from the senses becomes } \\
\text { the source of truth in this theory. No innate } \\
\text { idea. That everything captured by the senses } \\
\text { is a reference to the success or failure of the } \\
\text { process of education or human development. }\end{array}$ \\
\hline
\end{tabular}




\begin{tabular}{|l|l|l|}
\hline (d) & Convergence & $\begin{array}{l}\text { When viewed from the concept of education, } \\
\text { theory }\end{array}$ \\
& & $\begin{array}{l}\text { two theories. Because it is a fusion of the } \\
\text { two as well as the theory of fitrah but not yet } \\
\text { comparable with the theory of Fitrah. } \\
\text { This theory tends to be worldly oriented. } \\
\text { Concerned the success measured the happiness } \\
\text { of the world alone. So arguably this theory is } \\
\text { value-free. Perhaps this influenced its leading } \\
\text { figures who are anthropocentric. }\end{array}$ \\
\hline
\end{tabular}

\section{Differences in the Education Process}

\begin{tabular}{|c|l|l|}
\hline No & Theory & \multicolumn{1}{|c|}{ Differences } \\
\hline A & Theory of Fitrah & $\begin{array}{l}\text { The process of education as a } \\
\text { charity field, because the form of } \\
\text { servitude. Because fitrah is the } \\
\text { potential of Islam. Obviously, this } \\
\text { is an attempt to manifest worship } \\
\text { to his Lord. }\end{array}$ \\
\hline B & $\begin{array}{l}\text { Theory of Nativism, Theo- } \\
\text { ry of Empiricism \& Con- } \\
\text { vergence Theory }\end{array}$ & $\begin{array}{l}\text { The educational process is profane } \\
\text { because there is no transcendental } \\
\text { element. }\end{array}$ \\
\hline
\end{tabular}

7. Differences in Aspects of Human Nature

\begin{tabular}{|c|l|l|}
\hline No & Theory & \multicolumn{1}{|c|}{ Differences } \\
\hline A & Theory of Fitrah & $\begin{array}{l}\text { Aspects of human nature consist of } \\
\text { biological, physical and spiritual (spiritual) } \\
\text { or here is spiritual nature. }\end{array}$ \\
\hline b & $\begin{array}{l}\text { Theory of Nativ- } \\
\text { ism }\end{array}$ & $\begin{array}{l}\text { Aspects of human nature are biological } \\
\text { and physical. }\end{array}$ \\
\hline
\end{tabular}




\begin{tabular}{|c|l|l|}
\hline C & $\begin{array}{l}\text { Theory of Empiri- } \\
\text { cism }\end{array}$ & $\begin{array}{l}\text { Aspects of human nature come from } \\
\text { experience or the environment. Because } \\
\text { humans are just white paper or tabula } \\
\text { rasa. Although there are biological and } \\
\text { physical. }\end{array}$ \\
\hline $\mathrm{d}$ & $\begin{array}{l}\text { Convergence The- } \\
\text { ory }\end{array}$ & $\begin{array}{l}\text { The basic aspect of human nature consists } \\
\text { of biological and physical without spiritu- } \\
\text { al (spiritual). }\end{array}$ \\
\hline
\end{tabular}

\section{Construction of Islamic Education Development}

In this section the author discusses the concept of development of Islamic Education. Understanding is a conception that comes from definitions, characteristics and so on. Then the concept is studied empirically to generate theory. So, the result of the theory of fitrah is the theory that explains that humans have nature (potential), that is the religious potential of tauhid (samawi) and tendency toward the truth. In the process of its development, it is also influenced by the environment and God's involvement. Then was born Islamic Education based on the Fitrah Theory.

Theoretically, fitrah is the potential of religious monotheism or tendency toward the truth/goodness that has been brought from birth. That is bestowed by Allah and passed down by parents, especially mothers with the term spiritual DNA to humans, children or learners. But there is a necessity to guard fitrah. It may change over time as influenced by parents, or in some commentaries interpreted more broadly as the environment. ${ }^{23}$

The sanctity of human nature should not only be preserved through formal ritual execution, but it needs to be continuously developed by strengthening the mindset of the community through the development of education that begins with the family environment,

23 Tafsir Maudhu'i Al-Muntaha (Yogyakarta: Pustaka Pesantren, 2004). 


\section{Triwidyastuti}

school environment, and community environment. ${ }^{24}$

Education of family environment is the first education received by the child as the foundation as well as the next educational benchmark for children. Therefore, this education should be worked out completely. Especially mothers play as madrasatul ula (the first school).

The next is school education in which learners and educator play an important role. So, with Islamic Education based on the Fitrah Theory, one can know how to make appropriate educational strategies and methods.

Society can also be called a collection of people who interact with each other that is bound by something (belief or religion, cultural heritage, social environment, family, politics, homeland, feelings, ideals and others to achieve the purpose of life. ${ }^{25}$ Through this container also humans can proceed or develop. Thus, the development of education in society is also necessary.

Then how does God develop the fitrah to humans?

a. God as the mover of all that moves (Causa Prima).

In a sense, God move by Himself to what is desired to man, can be $a q l$ or qalb. This is what is called the guidance. So, there is God's will. It cannot be observed empirically as it is normative.

b. God develops through genetics from parents.

This means that man's potential comes from the genetic factor, be it biological, physical and spiritual or known as biological and physical DNA. There is also a spiritual DNA. It's also called the theo-centric humanism.

The results related to Islamic Education Based on the Fitrah Theory are as follows:

24 Anas Salahuddin, "Filsafat Pendidikan," ,Filsafat Pendidikan/Anas Salahuddin 2011, no. 2011 (2011): 176, https://doi.org/2011.

25 Salahuddin,p. 83. 
The Fitrah-based Islamic Education in the author's view is an antidote of secularism in the world of Islamic education.

With the explanation that the Theory of Fitrah is a theoretical theory, the truth is sourced from God. It is different from anthropocentric secularism in which the source of truth comes from humans. It can be said that this secularism rejects metaphysical and tends to rationality. Another view about secularism says that it is the idea that separates God from man. In the late 18th century it began to affect the world of Islamic education because of the weak moral and intellectual Muslim world.

Without a doubt, Western secular civilization has caused radical changes in the Islamic world, especially in its political and educational domain. At this time the Muslim world can no longer claim that the problems of modernity are exclusively Western. ${ }^{26}$

In this case the author really wants to give a response. Islamic education must remain firm in its fitrah theory without denying the flow of globalization that Muslims inevitably must participate in it. The values of Western education may be promoted to a positive value and not against the concept or principle of Islamic education. All can go without dichotomy in education. Such as Islamic education is also concerned in general science or sometimes called the science of the world. So, let's begin to open up about the concept of the real theory of fitrah. So, Islam truly becomes Rahmatan lil 'alamin.

Islamic Education-Based Theory of Fitrah form a quality human or character according to the Qur'an.

The human soul is like a clay that is ready to be carved into as long as it suits the characteristics of the clay. So, as an effort of building the character of the nation then character education is a must. Character is mental traits, morals, or characteristics that distinguishes a person

26 Muhammad, Fitrah the Islamic Concept of Human Nature. 


\section{Triwidyastuti}

from others. ${ }^{27}$ In the Qur'an man has actually been described as a hanief creature; tends to righteousness and monotheism.

How then we can develop human with this the quality and character? In his book Maragustam S iregar conveys the following thought: The first pillar is habituation and good culture. The second pillar is teaching the good things (moral knowing). The third pillar is moral loving and feeling, feeling and loving good. The fourth pillar is moral acting (good action). The fifth pillar, exemplary model and the surrounding environment. The sixth, repent (back) to God after making mistakes. ${ }^{28}$ These six pillars can be implemented in the formal, informal and non-formal education process.

\section{E. Conclusion}

\section{Theory of Fitrah in Islamic Education}

The Fitrah theory linguistically has some definitions given by some of the figures of Islamic Education Philosophy. Yasin Muhammad said fitrah is the human tendency to monotheism and truth. MurtadhaMuthahari says that it is the potential of goodness brought about from birth. This is similar to the opinion of the philosopher of Indonesian Islamic Education Hasan Langgulung. While Sayyid Qutb said fitrah is the potential of Islam. Etymologically, looking at the Dualist-Active view proposed Yasin Muhammad, Fitrah is a tendency to monotheism or truth, potential goodness and potential for religion of Islam.

\section{Theories of Nativism, Empiricism and Convergence}

The theory of Nativism is a theory that says that the process of human development is only influenced by heredity factor alone, or commonly called talent/congenital. So, factors outside heredity or the environment have no effect. This theory is anthropo-centric in the sense that the human development process does not involve God. The famous figure of this school is Arthur Schopenhauer.

27 Maragustam, Filsafat Pendidikan Islam,p. 244.

28 Maragustam,p. 264-271. 
The theory of Empiricism is the theory that humans are born like white paper or Tabularasa that does not bring any talent or anything. The leading promoter of this theory is John Lock who is the most famous figure in the Empiricism Theory. So, according to this theory, human development is only influenced by environmental factors only. Sensory experience becomes the source of truth. So, this theory also does not involve God in it (anthropo-centric)

The theory of Empiricism is the merging of the above two theories. Talent/congenital and environmental factors affect the process of human development. But just like the two theories above, this theory is anthropo-centric using rationality as the source of truth. The figure of this theory is William Stern.

Comparative Analysis and Construction of Islamic Education Based on the Fitrah Theory

This comparative analysis between the Fitrah Theory, Nativism, Empiricism and Convergence theories is based on human nature. Theory of Fitrah suggests the connection between society, self, environment and God. The Nativity Theory emphasizes the dominant hereditary factor and the Empirical Theory stresses on the environment. Theory of Convergence combines both heredity and environment but does not give God a role. Then, the prominent distinction between the Theory of Fitrah and Principles of Western Education Philosophy is difference between theo-centric and anthropo-centric paradigms.

Therefore, based on the above explanation the Theory of Fitrah is the most appropriate theory to be used in the world of Islamic Education without having to mingle it with the principles of Western Philosophy. Some of its positive values, however, can be absorbed such as advancement in terms of technology, a more advanced educational system or a positive value assumption to the life of the world.

So, the world of Islamic Education should not necessarily use the Theory or Western principles as there is already a well-established 


\section{Triwidyastuti}

theory in the world of Islamic Education. This is important, as argued by Hujair Sanaky, to avoid inconsistency in the world of Islamic Education. 


\section{REFERENCES}

Achmad Arifudin. "Prinsip prinsip pendidikan islam perspektif alquran dan hadis." Education, 23:10:46 UTC. https://www. slideshare.net/achmadarifuddin/prinsip-prinsip-pendidikanislam-perspektif-alquran-dan-hadis.

An Nawawi. "Darul Kutub Al- 'Ulumiyah.” STUDI HADIST TENTANG FITRAH MANUSIA (Sebuah Kajian Ontologi) (blog), Desember 2014. https://pecinta-araby.blogspot.com/2014/12/studi-hadisttentang-fitrah-manusia_3.html.

Firman, Arham Junaidi. "Paradigma Hasan Langgulung Tentang Konsep Fitrah Dalam Pendidikan Islam." Jurnal Pendidikan Islam 8, no. 2 (29 November 2017): 123-43.

Ismail, Faisal. Paradigma Pendidikan Islam: Analisis Historis, Kebijakan, dan Keilmuan. Bandung: Rosdakarya, 2017.

Ma'arif, A.Syafi'I. Pendidikan di Indonesia: Antara Cita dan Fakta. Yogyakarta: Tiara Wacana, 1991.

Maragustam. Filsafat Pendidikan Islam: Menuju Pembentukan Karakter Menghadapi Arus Global. Yogyakarta: Kurnia Alam Semesta, 2016.

Muhammad, Yasien. Fitrah the Islamic Concept of Human Nature. London: Ta-Ha Publishers, 1996.

Muthahhari, Murtadha. Bedah Tuntas Fitrah: Mengenal Jati Diri, Hakikat Dan Potensi. Jakarta, Indonesia: Citra, 2011.

Nata, H. Abuddin. Pemikiran Pendidikan Islam dan Barat. Jakarta: PT RajaGrafindo Persada, 2012.

Pujianto, Sarni. “Teori Konvergensi dalam Psikologi.” Sarni Pujianto (blog), Sabtu, Desember 2013. http://sarni72.blogspot. com/2013/12/teori-konvergensi-dalam-psikologi.html. 


\section{Triwidyastuti}

Qutb, Sayyid, dan Siddiq Fadzil. Di Bawah Naungan Al-Quran. Kuala Lumpur: ABIM, 1981.

Salahuddin, Anas. "Filsafat Pendidikan." ,Filsafat Pendidikan/Anas Salahuddin 2011, no. 2011 (2011): 1-99. https://doi.org/2011.

Tafsir Maudhu'i Al-Muntaha. Yogyakarta: Pustaka Pesantren, 2004. 